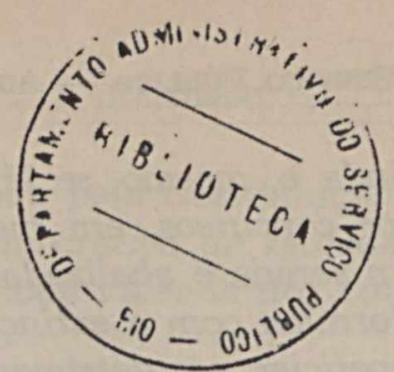

EDITORIAL

\title{
Seleção na Democracia
}

35. (81) $082.1: 321.8$

A condição básica da inexistência de privilégios sociais e, pois, da existência de igualdade de direitos (condição de que depende insofismàvelmente a democracia, por fôrça de sua própria definição) impõe à dinâmica do organismo republicano o princípio da livre eleição popular dos candidatos à ocupação, por prazos prèviamente limitados, dos postos do govêrno, que é então efetivamente emanado da vontade de todos na lógica consagração da vontade da maioria - sejam quais forem suas preferências. $E$ assim se assegura, em princípio, a participação de todo um povo livre em seu govêrno, em autodeterminação, através de seus representantes no poder, através de mandatos outorgados por sua vontade soberana e a serem em seu favor exercidos. Legitima-se, portanto, a democracia, uma vez que a dignidade de cada cidadão é assegurada pelo direito de eleger e ser eleito, na satisfação daquela fatal condição básica de igualdade de direitos (ressalvada apenas, naturalmente, a incompetência de exercício por menoridade, como por comprovada insanidade mental ou deformação moral).

Todavia, é evidente que o processo de eleição, erigido em princípio, só é praticável no tocante ao preenchimento dos cargos públicos essencialmente representativos, aquêles mais rigorosamente classificáveis como de atividades-fins, os quais se podem chamar cargos políticos, cujo exercício gravita no campo político pròpriamente. Eis, pois, que são cargos eletivos os de legisladores e chefes de executivo.

Em relação à seleção para os cargos mais considerados como administrativos - aquêles definíveis amplamente como de atividades-meios do govêrno - , na manutenção da condição "sine qua non" da inexistência de privilégios sociais, tornou-se necessária a adoção de um outro processo, a erigir-se num outro principio, para a salvaguarda da democracia. E êsse outro processo de seleção não pode ser senão o-de concursos de provas para o confronto da capacidade dos candidatos diante das atribuições dos cargos públicos. 
Muito se ouve ainda e, mesmo, se lê sôbre a deficiência do processo de seleção por concursos, em manifestações de descontentes que não encaram serena e abalizadamente a solução adotada, ou que não se conformam com a extinção de apadrinhamentos de que se poderiam beneficiar, em detrimento do regime democrático, é óbvio. Exemplos de má colaboração de questões de provas e de falta de objetividade nessas questões, em relação aos cargos a serem preenchidos, são freqüentemente mencionados - em solércia, em mentira, geralmente, e com apresentação de fatos por analisar, às vêzes. Contudo, embora se tenham que admitir falhas no processo, sendo a perfeição um ideal em cujo sentido nos cumpre apenas avançar decididamente, não se pode, em sã consciência, condenar o concurso de provas. Ninguém até hoje nos apresentou um substitutivo. Alguns preconizam cursos em substituição. $\mathrm{Na}$ da de novo. Cursos implicam em provas. $E$ os que decidem valer-se de concursos têm cursos à sua disposição, inclusive muitos mantidos como gratuitos pelo poder público. Por outro lado, não se Ihes nega o valor do autodidatismo, porém. Enfim, se o concurso é um processo de alguma forma superável, apresentem, os que o condenam, melhor processo de seleção democrática.

Quanto à algumas vêzes alegada falta de honestidade na execução e no julgamento das provas, o argumento não procede. Quem realmente tem conhecimento de falta de lisura na seleção pode incriminar os responsáveis (e tem o dever de fazê-lo, para afastar de si a mácula da conivência). Acusações tão ǵraves não levadas às últimas conseqüências, para a punição dos apontados como culpados, têm o mesmo valor das cartas anônimas...

Há ainda os detratores do processo de seleção por concurso que alegam não estarem as provas completamente livres da possivel interferência desonesta dos que as elaboram ou aplicam. Desconhecem êsses os cuidados, por qualquer cidadão verificáveis, que se tomam para eliminação de fraudes. De qualquer forma, se julgarem que as inúmeras e criteriosas normas acauteladoras firmadas não são suficientes, que sugiram outras ou que providenciem a vinda de provas de concursos do céu, lacradas, e consigam sua aplicação pelas insuspeitas e infalíveis entidades, por certo divinas, que para tal conceberem...

Em suma, qualquer pessoa medianamente esclarecida e bem intencionada poderá julgar a inconsistência dos argumentos que se opõem ao "regime do mérito" no provimento dos cargos públicos, 
em boa hora determinado pela Constituição Brasileira, em coerência com a condição democrática da igualdade de direitos, de vez que qualquer cidadão pode valer-se dos concursos promovidos em órgãos do govêrno.

Do plano do serviço público federal, em exemplo impositivo pela equanimidade e objetividade, a instituição de concursos de seleção de pessoal expande-se para os campos das administrações estaduais e municipais, atingindo até as emprêsas particulares.

Assim, no Brasil, na nossa Capital Federal e nas principais cidades da República, a necessidade de preparação dos que pretendem, em livre competição, conquistar situações funcionais nos quadros da administração pública e, já por efeito do exemplo desta, nos de administrações privadas, provoca o benefício cultural do funcionamento de crescente número de estabelecimentos de ensino especializado - fàcilmente organizáveis em razão da não necessidade de cumprimento de formalidades oficiais e da mobilidade de seus programas, que variam em função das variações do mercado de trabalho, numa linha auxiliar dos cursos de ensino comum, oficiais ou oficializados.

Entrementes, sob a liderança dos cursos de administração de iniciativa governamental, que naturalmente sâo os de mais ampla organização, pesquisas sôbre métodos administrativos empolgam cada vez maior número de estudiosos. Matérias de grande objetividade cujo estudo era descurado por falta de motivação (como estatística, relações públicas, psicotécnica, atuarismo, etc.) integram hoje criteriosos programas. De resto, no estudo de disciplinas de cultura geral (como a matemática, o vernáculo e a geografia) acentua-se um sentido ativo, racional e essencialmente utilitarista, enquanto questões antes fortemente controvertidas (como inúmeras do vernáculo) vão sendo esclarecidas convenientemente, no entrosamento vivo do estudo com a vida prática, em função da observação direta da realidade, ante a necessidade de pronta e decidida aplicação de conhecimentos e conclusões.

Verifica-se, pois, que, determinante de cursos intensivos e estimulante do autodidatismo, constitui-se a realização de concursos de provas de capacidade em destacado fator de aculturação, a par de firmar-se como um elemento de salvaguarda das instituições democráticas. 